\title{
Zhao Ziyang's vision of Chinese Democracy
}

Andrew Nathan

\section{OpenEdition}

\section{Journals}

\section{Electronic version}

URL: http://journals.openedition.org/chinaperspectives/4223

DOI: 10.4000/chinaperspectives.4223

ISSN: 1996-4617

\section{Publisher}

Centre d'étude français sur la Chine contemporaine

\section{Printed version}

Date of publication: 1 July 2008

Number of pages: 136-142

ISSN: 2070-3449

\section{Electronic reference}

Andrew Nathan, «Zhao Ziyang's vision of Chinese Democracy », China Perspectives [Online], 2008/3 | 2008, Online since 01 July 2011, connection on 24 September 2020. URL : http:// journals.openedition.org/chinaperspectives/4223; DOI : https://doi.org/10.4000/chinaperspectives. 4223

(c) All rights reserved 
ル

\title{
Zhao Ziyang's Vision of
}

Chinese Democracy

\author{
ANDREW I. NATHAN
}

$\mathrm{H}$ ow thorough a democrat was Zhao Ziyang? This is an important question if one believes that political change in China is likely to come from the top down. Although the Party chiefs say they are leading China toward democracy, there is much debate about what they mean. ${ }^{(1)}$ Among recent CCP leaders, Zhao was probably the most sympathetic to a conception of democracy resembling Western views. Others around him may have been more radical, such as Bao Tong and Li Rui (who wrote prefaces for this book), Li Shenzhi, and Zhao's conversation partner Zong Fengming, ${ }^{(2)}$ but they were not in a position to implement their ideas. Zhao had been in such a position. His views give us a sense of the likely outer limits of the ideas about democracy that might be held within the leadership, at least in his generation and probably in the current, apparently more conservative, generation of leaders as well. Among sources on Zhao, this book is a precious document. Before its publication we had two pieces of evidence to help us assess Zhao's views on democracy. Wu Guoguang's book on the work of the Political Reform Office in 1987 described the discussions that led to the proposals for separating Party and government and Party and enterprise management in Zhao's Political Report to the $13^{\text {th }}$ Party Congress. ${ }^{(3)}$ The Tiananmen Papers described Zhao's decision-making under pressure during the 1989 crisis, when he believed (as he repeats here) that he could have solved the crisis if Deng Xiaoping had agreed to withdraw the threat to punish the student demonstrators implied in the April 26 Renmin ribao editorial. ${ }^{(4)}$ But these books left many questions unanswered. The Political Reform Office discussed many subjects, but Zhao seldom revealed his own views. The events of 1989 revealed Zhao's instincts in dealing with an immediate crisis but did not expose his thoughts about long-term political reform. The new book is thus a valuable addition to a small corpus.

Zong Fengming was an old friend of Zhao's who had entered the Party at the same time and worked together with him in central China during the revolution. After 1949, Zong served in such posts as Party secretary in the
University of Aeronautics and Astronautics (Hangkong hangtian daxue) and adviser to the State Economic Reform Commission (Guojia tigaiweı) $\left(17^{(5)}\right)$. From July 1991 to October 2004, a period of 13 years, Zong visited Zhao at his home for a series of more than 100 meetings. With Zhao's knowledge, Zong went home and took notes from memory (zhuiji), saving them to publish after Zhao's death, which occurred in January 2005.

But the evidence in Captive Conversations needs to be interpreted carefully. Even though the loss of political power freed Zhao to talk with Zong and other visitors, we gather from allusions scattered throughout the book that he still had to be careful about what he said. Zong's account of Zhao's conditions of house arrest is not only fascinating in itself as a glimpse at how the Party deals with

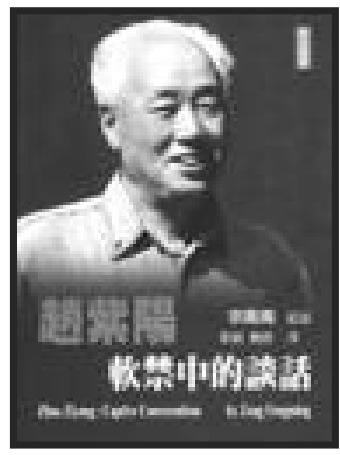

Zong Fengming, Zhao Ziyang: Captive Conversations

(Zhao Ziyang: ruanjinzhong de tanhua), Hong Kong, Open Books, 2007, $400 \mathrm{pp}$.

1. For example, John L. Thornton, "Long Time Coming: The Prospects for Democracy in China," Foreign Affairs, January/February 2008, pp. 2-22; Andrew J. Nathan, "China's Political Trajectory: What Are the Chinese Saying?" in Cheng Li, ed., China's Changing Political Landscape: Prospects for Democracy, Washington, D.C., Brookings Institution Press, 2008, pp. 25-43.

2. On Zong's ideological evolution, see his memoir, Lixiang, xinnian, zhuiqiu: wo de rensheng huigu yu fansi jian he Zhao Ziyang tanhua de yixie huiyi (Ideals, faith, and search: recollections and reflections on my life, with some reminiscences of my conversations with Zhao Ziyang ), Hong Kong, Huanqiu shiye [Xianggang] gongsi, 2005.

3. Wu Guoguang, Zhao Ziyang yu zhengzhi gaige (Zhao Ziyang and political reform), Hong Kong, Taipingyang shiji yanjiusuo chubanshe, 1997.

4. Zhang Liang, comp., Andrew J. Nathan and Perry Link, eds., The Tiananmen Papers, N.Y., PublicAffairs, 2001. This is based on the fuller set of documents in Zhang Liang, comp., Zhongguo 'liusi' zhenxiang (The truth of China's 'June Fourth'), 2 vols., Carle Place, Long Island, Mingjing chubanshe, 2001. In Captive Conversations Zhao spends considerable time reminiscing about key events in 1989. These reminiscences are consistent with the material contained in TAMP.

5. Numbers in parentheses refer to pages in the book. 
its fallen leaders, but also provides a necessary context for interpreting Zhao's remarks.

\section{Zhao's conditions of house arrest and the conversations}

Zhao spent his fifteen-and-a-half years of house arrest at Number 6 Fuqiang hutong, in Beijing. Zong says that the house was previously occupied by Hu Yaobang (1), so it must not have been Zhao's own house or one he had occupied previously, but one assigned by the central Party apparatus for the purpose of house arrest. It was a traditional Beijing siheyuan with three courtyards. Zong says that the street was quiet and the house was guarded by a group of soldiers posted inside the big front gate. The front courtyard was occupied by the guards and by a secretarial office and sleeping rooms. The second courtyard was Zhao's study, and the inner courtyard contained the family living quarters. Besides Zhao and his wife, Liang Boqi, the compound housed one of their daughters and her husband and son.

Zong believed that he was Zhao's first visitor when he came in July 1991. He got in by announcing to the guards that was a qigong master with an appointment. The guards demanded his ID and he claimed to have forgotten it. After a bit of shouting back and forth to one another, the guards let him in and did not register him.

Zong divides the series of meetings into two periods. The first 47 meetings through September 1997 were conducted under relatively relaxed conditions. In that month Zhao wrote a letter to the $15^{\text {th }}$ Party Congress calling for a re-evaluation of the June Fourth incident, and the letter was leaked to the international press via Hong Kong. In response, the leadership tightened restrictions on Zhao. The second set of 34 meetings from 1998 through 2004 occurred less frequently, and less of interest was said (or at least reported here).

The first six of the meetings took place while the Party Centre was still conducting its investigation of Zhao. Then in October 1992 a delegation consisting of Qiao Shi, Song Ping, Li Tieying, and Ding Guan'gen visited Zhao and told him that the investigation into his case was finished and that the "two conclusions" would not change. (These were the conclusions of the Fourth Plenum of the $13^{\text {th }}$ Central Committee that Zhao had "supported turmoil" and "split the party.") Zhao demanded to learn the findings of the investigation and that they be published within the "appropriate circle," but neither of these requests was granted. Zhao and his friends felt sure that the investigation - led by Wang Renzhong (67) - had turned up nothing. But they believed that because Deng Xiaoping's prestige was on the line the results were predetermined.

The high-ranking visitors informed Zhao that his freedom was restored. However, they added, in using this freedom he should observe discipline, not go out during the $14^{\text {th }}$ Party Congress, which was being held that month, and not see reporters (64-65). Gradually Zhao was able to see a few more visitors in addition to Zong. These included Liao Jili, Yu Guangyuan, and Cai Decheng (94ff., 104 ff., 115 ff.), retired pro-reform officials with whom Zhao discussed economic theory, socialism, Marx's ideas, problems of building socialism in a backward society, and so forth. They also included Yang Jisheng, Shi Binhai, and Zhang Guangyou, high level Party journalists who sympathetically interviewed Zhao, although not for publication (195, 211-17, 232, 245). But as time went by, the extent of Zhao's freedom proved limited. For example, he was denied permission to go to a high-level cadres' fitness club near Zhongnanhai to play tennis. When he insisted that he would walk, his minders yielded, but they would take him only on Tuesday and Thursday mornings, when the club was not open and no one else was there (101-102). Likewise when Zhao wanted to play golf he was allowed to go only to a specific course where, presumably, he would not attract attention (102).

As the restrictions imposed after the ostensible 1992 freeing became clear, Zhao and his friends were outraged. Zhao wrote letters to Jiang Zemin to protest, claiming that the restrictions violated the Party and state constitutions. Word was passed back that he should behave more like Hua Guofeng, who voluntarily kept himself out of sight because of his regard for political stability (102). Zhao and his friends speculated that the regime believed that any public appearance by Zhao would be a threat to Jiang's power. They complained that Jiang cared only about staying in power, not about any vision for China (117).

Even so, the conditions of house arrest were loose enough so that Zhao was able to write and distribute his letter to the $15^{\text {th }}$ Party Congress. He used Zong to pass along two of the copies, and we are not told how he passed the others (259). Zhao thought about asking Wan Li and Yang Shangkun to write similar letters urging the party to correct the historical record about June Fourth $(249,251)$, but ultimately he was the only one to write. After the leak of the letter, all of Zhao's guards were changed (265), his daughter and her family had to move out (265, although in 2002 it is mentioned that she is living there again because Zhao's wife is not well), he temporarily lost his ability to have visitors except for direct relatives, and he could not go out to play 
golf $(260,261)$. All this, he was told, was not house arrest, but was for social stability (339).

Eight months after this tightening, in May 1998, Zong Fengming was able to visit again, arranging in advance by telephone for Mrs. Zhao to meet him at the outer gate, where he argued to the guards that he was an old revolutionary comrade of hers, over 80 years old, who had travelled a long distance, and that it would be "tai shuobuguoqu" not to let him come in. Somehow this worked (265). Again, and he doesn't say how, he managed to get in on June 4, 1998 (266), and on a series of occasions thereafter. But the conversations were now more constrained. Eventually things eased up again; we learn that Zhao played golf, and, in 2003, that he travelled outside of Beijing $(339,346)$. Zong was again able to bring guests with him from time to time $(311,318,356)$.

During both periods of confinement Zhao and his wife evidently lived with considerable anxiety. Zhao held his conversations with Zong on wicker chairs that he brought out into the courtyard to avoid bugging (1, 63, and elsewhere). Zhao's wife kept an eye out in all directions while they were talking lest there be someone taking photographs. In a 1993 conversation, Zhao referred to the possibility that if the leftists were to gain strength he could be gotten rid of in a staged car accident (137). Another time he mentioned the possibility that his house might be ransacked (141). Zhao talked often about how the government sent Bao Tong to jail as a way of hurting him (e.g., 244). At one point Zhao had Zong pass a message to Bao telling him to be careful so as not to cause too much trouble for himself. But Bao turned down this advice, saying he had been warned by the authorities but intended to continue to talk to foreign reporters and was not afraid of going back to Qincheng Prison even if he would never emerge from a second imprisonment alive (276).

In the conversations, Zhao seems well informed, but it is not clear how he got information. He mentions the idea of writing his memoirs (75), but says that he is denied access to his own papers, even his public speeches $(29,102,186$ and elsewhere). He discusses with approval books by $\mathrm{He}$ Qinglian (Xiandaihua xianjing, 224, 300), Gordon Chang (The Coming Collapse of China, 333), and Gao Wenqian (Wannian Zhou Enlai, 354). He mentions watching television (232). And he is aware of a conference of Chinese scholars on Chinese reform that took place at Columbia in 2004 (384). As I recall, this conference was reported in the New York Chinese language press, and Zhao may have read about it in a periodical such as Cankao xiaoxi.
Zhao and his visitors gossip about current political events. In the early 1990s Zhao's friends watched the political battle in the leadership and speculated that Deng might bring Zhao back to power. Zhao says it will never happen. Because Yang Shangkun does not support what was done on June 4, Deng can no longer trust him, fearing that the verdict would be reversed under a Yang leadership. Hence the Yangs are out of power and Deng cannot get rid of Jiang Zemin and Li Peng, no matter how dissatisfied he is with them $(59,73-75,101,156,186)$. Deng is trapped by June Fourth and cannot bring Zhao back (125). The friends watch disapprovingly as Jiang Zemin consolidates power and builds himself as "core," with elements of a cult of personality (242).

In his conversations with Zong, Zhao seems to have spoken intentionally for posterity, summoning Zong when he wanted to say something and setting the topics for the conversations. ${ }^{(6)}$ But he spoke guardedly. He often talked about how to respond to problems that he thought China was facing, but he never made a clear statement about what form of political system would be best for China in principle. Zhao's thoughts went through a further filter when they were put into notes by Zong. Because of the presence of guards, Zong could not make recordings or take notes on the spot, but went home and wrote notes from memory after each meeting. However, Zong says, Zhao reviewed the manuscript as it was written $(19,399)$, which must have provided an opportunity to correct errors, but potentially also to soften statements that may have been too frank. Besides Zhao, other people contributed to the manuscript. Zong thanks $\mathrm{Du}$ Runsheng, Li Rui, Hu Jiwei, An Zhiwen, and Bao Tong for reviewing the manuscript and offering corrections, noting that Li Rui went over the entire manuscript carefully and offered revisions for "choice of words, implications, and punctuation” (399). These people may have altered Zhao's formulations to make them either stronger or weaker.

In short, what we have here are neither Zhao's literal words nor his unmediated thoughts. This makes it hard to be sure that the book gives us a full, accurate grasp of his thinking. On the one hand, Zong and other editors such as Li Rui may have sharpened some of Zhao's ideas. Alternatively,

6. The facts discussed in this paragraph are inconsistent with the statement that Zhao was opposed to publishing the book given by Zhao's family members to Perry Link. Link, "He Would Have Changed China," The New York Review of Books 55:5 (April 3, 2008), http://www.nybooks.com/articles/article-preview?article_id=21203, accessed August $31,2008$.

7. Zhou Tianyong, Wang Changjiang, and Wang Anling, eds., Gongjian: Zhongguo zhengzh tizhi gaige yanjiu baogao, Wujiaqu, Xinjiang shengchan jianshe bingtuan chubanshe, 2007. 
Zhao may have made indirect statements that he counted on Chinese readers to understand as meaning more than he explicitly said. This is one possible implication of Bao Tong's sarcastic remark in his preface, challenging the censors to find anything here that would justify banning the book - as of course they did - from import from Hong Kong (11). Despite all these caveats, the book offers new insight into Zhao's views on democracy.

\section{Zhao on democracy}

Zhao's conversations with Zong are not the systematic thoughts of a political philosopher, or of a policy study group such as the Party School group, whose recent blueprint for political reform, Gongjian, in many ways resembles Zhao's ideas, ${ }^{(7)}$ but rather the wide-ranging, somewhat miscellaneous ideas of a political actor who is interested in current problems and practical solutions. Zhao believed that most of China's problems in the 1990s could be addressed by opening up the Chinese political system without creating a challenge to CCP rule, and he optimistically believed that such a controlled opening was realistically possible.

Zhao's views on current political problems are embedded in a stage view of social change. According to a theory that he adopted from liberal brain-trusters when he was in power, and which is still in official use today, ${ }^{(8)} \mathrm{China}$ is in the "preliminary stage" (chuji jieduan) of socialism. This is the stage at which a developing country moves from poverty to moderate wealth by developing a commodity economy according to the rules of the market - a process also described as "making up missed lessons" of capitalism, because in Marx's theory this stage of economic development should have taken place before the socialist revolution (45, elsewhere).

Zhao says that he used to believe that the country needed strong authoritarian leaders to force the bureaucracy to accept this yielding of power for the purpose of modernisation - the view known in China as neo-authoritarianism (234). He says he had nothing directly to do with Wu Jiaxiang, the party theorist who coined that term when Zhao was in power, but that he was aware of it and agreed with it at the time. But, he says, his view changed in 1987 when he moved from the premiership to the post of general secretary.

Before 1987 I didn't concern myself with [political democracy] much. First, [as premier] I was working on economic reform [not political reform]; second, I was very busy with the work of the State Council and had no time to think about it; also, I did not under- stand ideological issues well; and finally there were other people handling that area. After I became General Secretary in 1987 I started to explore it. My general view was that the Party interfered too much in government departments and mass organisations. It concerned itself with all kinds of matters. Likewise the Party interfered in various aspects of individuals' lives, including private life. This was no good. I once brought up the idea that there should be less interference in literary works, not meaning that there should be no management, but that we should set a direction for a given time - what should be praised, what should be opposed - and make this clear. But with respect to specific works we should not interfere, the Party committee should involve itself little, and as long as a work did not violate the law we should not manage it. On this point Wang Meng [then Minister of Culture] told me this was a good policy and one that he supported. At this time my guiding ideas were, first, that the leading position of the CCP could not change, but the Party's form of leadership must change; second, that a socialist state should be a rule of law state (146).

Having become interested in political reform, Zhao came to think that China needed three categories of political change, although he does not divide them so clearly himself.

First, the Party should yield power over economic decisionmaking to provinces, enterprises, and individuals so that they can manage efficiently their own affairs in the commodity economy (46, 79-82, 149, elsewhere). The previous need for repression grew out of the decision to rely on will power and political commands to push an immature economy to develop. Under reform, development is promoted by incentivising it, so that it occurs as a consequence of people's voluntary actions (92-93). Zhao uses democracy and rule of law as labels for management methods that suit the commodity economy because they allow people to make their own decisions (129). Also, he notes that social group interests will diversify under market conditions, which he says makes the demand for democracy a global trend (148-149, elsewhere).

Second, democracy involves changes in the inner workings of the ruling party (dangnei minzhu). The devolution of

8. The term is officially translated as "primary stage." See, for example, Hu Jintao's political report to the 17th Party Congress, 15 October 2007, http://www.china.org.cn/english/congress/229611.htm, accessed 30 August 2008. 
power for economic growth gives rise to corruption and polarisation of wealth $(239,383$, elsewhere). These developments are contrary to the Party's ultimate Marxian goals - which he still believes are glorious - and could be fatal to its hold on power. The only way to check such trends is to let society supervise those in power. If power is too concentrated then corruption cannot be stopped. Leninist partybuilding techniques are no longer appropriate. The Party must renew itself (ziwo gengxin).

In this category of intra-Party democracy, Zhao offers five specific ideas. First, big decisions should be made in fact and not only in theory by the full Politburo, not by the smaller Standing Committee or by the General Secretary alone, and leadership should be exercised on a rotating basis by PBSC members to avoid over-concentration of power in one person. Second, Party, government, and financial affairs should be open (gongkai); cadres should be selected not by black-box command methods but by multi-candidate direct elections, at the village, township, county, and municipal levels "at first" (but what later on? - he does not say). Third, the Party should let the masses "participate in managing" (canyu guanli) their own affairs, for which Zhao again uses the term "social democracy." This means that party officials should not interfere in the decision-making scope of enterprises and government agencies. To reduce its practice of doing so, the Party should abolish the various duikou structures which place every government organ under a corresponding Party body through Party cells and committees. Also as part of social democracy, channels should be created for dialogue with farmers, workers, and intellectuals. The work of supervision (jiandu gongzuo) should be carried out by trade unions in industry and villager self-government organs in the villages.

Fourth, the Party should allow freedom of speech, so that public opinion can supervise government (yulun jiandu), because this is the only effective way to prevent corruption and official abuse of citizens' rights (gongmin quanli). The people should have access to information so as to increase transparency (zengjia toumingdu). Allowing the "human right" (renquan) of freedom of speech, Zhao notes, is appropriate. It is not the same thing as democracy: Hong Kong under the British, he says in 1994, is not a democratic system, but human rights are protected there (132-133). Fifth, the Party's political thought work should be reformed to get rid of leftist influences and unify thinking around Deng Xiaoping's theory of reform and opening (all five points from pp. 166-167 with some details added from a passage where the same ideas are stated on pp. 148-149).
Zhao's third set of ideas about democracy involve the state system itself - that is, the set of institutions that most Westerners have in mind when we think about whether or not China will democratise. On this subject, Zhao's ideas were cautious for the near term and vague about the long term.

When we say we must modernise, it is no different from saying we have to Westernise - to implement the whole Western package (shixing Xifang de yitao). But to implement Western multiparty politics and parliamentary government won't do at present.... As China's leadership levels develop, several different groups may emerge (keneng hui chuxian jitao mache). At the leadership level China should put stress on the functions of the NPC and CPPCC to create some power balance; carry out local self-government, develop the functions of the mass organisations, including the trade union and women's association and of the [united front] democratic parties (minzhu dangpai), so as to create a framework in which the representatives of various [social] interests balance one another through the NPC and CPPCC. After going through that transition, the next step of implementing democratic politics and establishing a democratic political structure will be relatively realistic (171).

He does not say, however, what this next step will be or what stage of economic development will make it possible. Zhao acknowledges that it is not obvious how to make these general principles work. The time is not ripe for multiple political parties, because that would endanger CCP rule $(184,344)$. But Sun Yat-sen's idea of tutelage was right: the people should be led by stages to accept constitutional government (xianzheng). Meanwhile, China might benefit from parliamentary democracy (yihui minzhu). Gu Zhun - a Cultural Revolution victim whose philosophical writings were published posthumously in 1994 to great acclaim - was right in saying that parliamentary democracy is eventually necessary, Zhao says $(183,231)$. But what does this mean? Zhao clarifies that parliamentary democracy means the existence in parliament of a legal opposition faction (hefa de fanduipai) that does not challenge the ruling party's hold on power. This was the system he understood to be in place in Taiwan at the time he was speaking $(116,219)$.

Taiwan is a small place and the people's levels of education and culture are different from ours. They went 
through a transitional period and now they have one large party and one small party. At this point they still can't have alternations in power, but they have a legal opposition faction (234).

He once thought such a system would naturally emerge in China, but it has not.

I used to think that after the strongman Deng Xiaoping departed, people with various different political views would emerge in the Party Centre and would check one another. But now it appears that this view was wrong. As soon as they get into power they form a single interest group, and to protect the vested interests of this group they take a unified position towards everyone on the outside (340).

Zhao acknowledges that implementing a parliamentary system in China would not be straightforward.

The most complicated problem is [the role of] the National People's Congress (NPC). The NPC is a power organ. For it to play its role involves the question of how it relates to its Party committee and to the government. If the Party exercises its leadership through the Party members who are delegates so that the will of the Party becomes law, then this is not reform; the Party members vote together and the NPC has no function. But if the Party members are freed from their Party roles to decide for themselves how to vote in the NPC, this could create chaos (147)

Below the central level, Zhao's ideas for reform of the state system are even less fully developed.

As for basic-level democracy (jiceng minzhu), we need to put people managing their own affairs on the agenda. The masses should manage their own affairs as much as possible, we should protect citizens' rights these should be protected by law.... Each unit should basically carry out direct democracy (zhijie minzhu), first of all democratic elections to carry out villager selfgovernment (cunmin zizhi). The cities can also implement direct democracy and so too for xian magistrates. Provinces should have multi-candidate elections (cha'e xuanju). Single-candidate elections without choice can hardly be called direct democracy (147).
There can, he concludes, be no single model. The goal of political reform is to protect fairness of distribution and hence allow the development of a large middle class (230). Society will find its way through practice. As Zong Fengming summarises, economic growth combined with fair distribution remain Zhao's key goals, with political reform a means to that end (395).

Zhao, in short, believed in what we might call "glasnost authoritarianism" for the China of his day - a system of oneparty rule with enough political openness to allow citizens to criticise officials but not enough to allow a rival political force to overthrow the ruling party. His belief in such a model rested on an implicit premise: that the regime did not have enemies strong enough to take advantage of openness to overthrow it. It was a premise that many of Zhao's highlevel colleagues did not accept during Tiananmen and do not accept now. The Tiananmen Papers are full of reports from the state security authorities, the Beijing municipal Party committee, and others warning that domestic and foreign enemies were using the student demonstrators to pose a mortal threat to the regime. ${ }^{(9)}$ Since 1989, the regime has argued tirelessly that the repression saved China from the fate of the Soviet Union. ${ }^{(10)}$

Zhao, however, looking back on 1989 in his conversations with Zong, held to his original view. He believed that the students were willing to leave the Square right after $\mathrm{Hu}$ Yaobang's memorial service, but that they were held there by the fear of repercussions: to remove that fear would have been the key to settling the conflict. He says he could have made peace with the students through dialogue on three occasions. First, the students would have gone back to classes after they held their own ceremonies to mourn $\mathrm{Hu}$ Yaobang, if Zhao's instructions had been followed to talk to them respectfully without sharpening contradictions. Instead, while he was on an official visit to North Korea, the hardliners persuaded Deng Xiaoping to issue the April 26 People's Daily editorial, which labelled the demonstrations a "turmoil" (dongluan) and thus threatened the students with retribution. Second, after his return from North Korea, Zhao signalled a softer tone in his speech to the Asian

9. On this point, the book makes an interesting new contribution to the historiography of Tiananmen. Zhao says that the ministries of public security and state security disagreed over whether George Soros - who set up a foundation in China in 1986 - was working for the CIA. The Ministry of Public Security said yes and the Ministry of State Security said no, so Soros's foundation came to China as a "guest" of the MSS. To be cautious, however, Zhao ordered his own subordinate unit, the Economic System Reform Institute (Tigaisuo), to cut ties with the foundation (67).

10. David Shambaugh, China's Communist Party: Atrophy and Adaptation, Berkeley, University of California Press, 2008. 
Development Bank and suggested that the Party take new steps to fight corruption, hoping to lower tensions and open a way to win over the students on the basis of "democracy and rule of law." But the hardliners undercut him again by insisting that he did not speak for the Party centre and that Deng Xiaoping's evaluation of the situation was irreversible. Third, at the May 16 Politburo Standing Committee meeting Zhao proposed to issue a revision of the April 26 editorial's line, and to take public responsibility for its errors even though he had never had a chance to approve the text. Li Peng, however, blocked this proposal on the grounds that Deng Xiaoping's original words could not be changed (5053).

We will never know whether Zhao was right about the ability of one-Party rule to survive and even be strengthened by public criticism. But views like Li Peng's and Deng Xiaoping's continue to guide the Party today. The regime continues to choose repressive, rather than open, authoritarianism as its political model.

\section{Conclusion}

In interpreting Zhao, as any thinker, we have to attend both to the details of what he says and to the context in which he is speaking. In his conversations with Zong he was not engaged in the debate that engages many in the West whether China will become like the West - but in a different debate - how China can combine economic growth with justice. He answers questions we don't ask and doesn't answer questions we do ask. The word democracy means different things to him than it does to us.
In the end we cannot conclude that Zhao wanted to bring China toward democracy as we define it, although we also cannot conclude that his mind was closed to that long-term outcome. The Zhao of these conversations was committed to no specific political endpoint. He viewed political institutions as instrumental rather than primary, designed to serve the more fundamental goals of economic development plus fair distribution, a combination he referred to as "scientific socialism." He was willing to adjust political institutions as new challenges to these goals emerged.

Zhao's actions may have spoken more loudly than his words. His preference for dialogue during June Fourth showed an openness to the idea of political accountability. And as Zong points out, after June Fourth, Zhao broke with the tradition of purged leaders bowing to Party criticism. At the Fourth Plenum of the $13^{\text {th }}$ Central Committee he gave a speech refuting the Party's decision that he had done wrong (it is reprinted in Captive Conversations, pp. 6-21). Through the years of his house arrest he never bowed to the Party's tradition that he should accept blame. Zong Fengming praises this "Zhao Ziyang model" of personal integrity as a welcome contrast to the long line of previous CCP leaders from Peng Dehuai to Liu Shaogi, Deng Xiaoping, and Hu Yaobang, who yielded to the Party's demand to admit error even though history showed that their positions had been correct (14). In standing up for what he believed in, Zhao planted a small seed that could grow into a pillar of an eventual Chinese democracy. 